\section{Motor Stereotypy}

Douglas I. Katz

Department of Neurology, Boston University

School of Medicine, Braintree, MA, USA

\section{Definition}

A repetitive, purposeless simple or complex movement, posture, or utterance. Examples include rocking, head nodding, leg crossing, and marching in place. Motor stereotypies may occur in children with autism, mental retardation, and other developmental disorders or in children with normal development, although with a higher incidence of comorbidities such as attention deficit hyperactivity disorder, tics, and obsessivecompulsive disorder (Harris et al. 2008; Muthugovindan and Singer 2009). Motor stereotypies may be persistent, and a significant proportion of children have positive family histories of motor stereotypies (Harris et al. 2008). Motor stereotypies are distinguished from tics in that they are more rhythmic, often begin in children at a younger age, and are not associated with a premonitory urge.

\section{Cross-References}

$\checkmark$ Autistic Disorder

- Tic

\section{References and Readings}

Harris, K. M., Mahone, E. M., \& Singer, H. S. (2008). Nonautistic motor stereotypies: Clinical features and longitudinal follow-up. Pediatric Neurology, 38(4), 267-272.

Muthugovindan, D., \& Singer, H. (2009). Motor stereotypy disorders. Current Opinion in Neurology, 22(2), 131-136. 